\title{
Modulation of apoptosis of proliferating and differentiating HL-60 cells by protein kinase inhibitors: suppression of PKC or PKA differently affects cell differentiation and apoptosis
}

\author{
Jurate Savickiene ${ }^{1}$, Arunas Gineitis $^{\star, 1}$ and Torgny Stigbrand ${ }^{2}$ \\ ${ }^{1}$ Laboratory of Developmental Biology, Institute of Biochemistry, 2600 Vilnius, \\ Lithuania \\ 2 Department of Immunology, University of Umeå, S-90185 Umeå, Sweden \\ * corresponding author: A. Gineitis, Department of Biological Chemistry, Tupper \\ Hall, School of Medicine, UC Davis, CA 95616, USA. \\ tel: (530) 752 314; fax: (530) 752 3516; e-mail: aagineitis@ucdavis.edu
}

Received 27.4.98; revised 22.3.99; accepted 14.5.99.

Edited by P. Davies

\begin{abstract}
The relationship between RA- or dbcaMP-mediated differentiation and subsequent apoptosis in HL-60 cells was assessed by modulating the levels of differentiation suppressing the activity of PKC and PKA with calphostin C or GF 109203X and H89, respectively. Results demonstrated that (1) RA and dbcAMP caused a dose-dependent increase in apoptosis concomitant with progressive differentiation; (2) the suppression of PKC activity resulted in an increase of apoptosis unrelated to the modulated levels of differentiation; (3) the inhibition of PKA decreased granulocytic differentiation, but did not significantly affect apoptosis; (4) the pretreatment of cells with dbcAMP strongly potentiated RAmediated differentiation without apparent changes in apoptosis; (5) cell differentiation and apoptosis were associated with cell cycle arrest in G1 phase and G2/M phases, respectively. Our findings indicate that the functional maturity of differentiating cells is not directly related to the apoptotic programme, and suggest that induction of cell differentiation and apoptosis are regulated by separate mechanisms in which PKC and PKA are involved.
\end{abstract}

Keywords: HL-60 cells; differentiation; apoptosis; protein kinase inhibition

Abbreviations: AO, acridine orange; DMSO, dimethyl sulfoxide; dbcAMP, $N^{6}, 2^{\prime}$-O-dibutyryladenosine 3':5'-cyclic monophosphate; EDTA, ethylenediaminetetraacetic acid; ET, ethidium bromide; GF 109203X, bisindolylmaleimide I; HCl $\}$, Clp, calphostin C; H89, $\{\mathrm{N}$ [2((p-Bromocinnamyl) amino) ethyl]-5-isoquinoline sulfonamide; NBT, nitro blue tetrazolium; PI, propidium iodide; PKA, cAMPdependent protein kinase; PKC, protein kinase C; PMA, phorbol 12 myristate 13-acetate; RA, all-trans retinoic acid; RNAse, ribonuclease; SDS, sodium dodecyl sulfate; TB, trypan blue; Tris, 2-amino2-(hydroxymethyl)-1,3-propanediol

\section{Introduction}

Neoplastic myeloid cells are derived from cells, which diverse from the natural differentiating pathway at distinct developmental stages, most often as myoblasts ${ }^{1-6}$ or promyelocytes. 5,6 The common feature of these neoplastic cells is their capacity to return to the differentiation pathway by exposure to certain chemical agents. ${ }^{7-9}$ At certain conditions proliferating or differentiating leukemic cells undergo apoptosis as well. ${ }^{10-12}$ Human promyelocytic leukemia HL-60 cells have been used repeatedly to study the control mechanisms of proliferation, differentiation and apoptosis. ${ }^{5,8,9,11,13,14}$ Besides compounds such as sodium butyrate and dbcAMP, HL-60 cells can be induced to differentiate to granulocytes by treatment with all-transretinoic acid (RA) or its isomers. ${ }^{14}$ Due to this property retinoids have been proposed as future radical therapeutics for acute promyelocytic leukemias. ${ }^{15,16}$ Recently, by in vitro experiments, however, it was demonstrated that HL-60 cells induced to differentiate to granulocytes undergo apoptosis. ${ }^{11,12}$ A large wave of apoptosis can be expected ${ }^{17}$ besides other side effects such as coagulation disorders and hyperleukocytosis. Apoptotic cells and products released during their degradation may cause the hyperleukocytosis. Thus, in vitro studies of the relationship between granulocytic differentiation and subsequent apoptosis may be useful for elucidation of the control mechanisms of normal hematopoiesis and for the strategy of differentiation therapy of leukemias as well.

Many evidences indicated remarkable changes in the activity of distinct protein kinases and phosphatases at all the stages of the HL-60 differentiation process. ${ }^{8,18-37}$ It has been shown that during granulocytic differentiation the commitment stage is associated with a modulation of the activity of PKC ${ }^{22,29,34}$ and $\mathrm{PKA}^{19,35-38}$ and PKC inhibitors are able to potentiate granulocytic differentiation. ${ }^{29,36,37}$ Recently, we have shown that inhibition of protein kinase PKA and PKC exert stage specific and inducer (RA or dbcAMP) dependent effects on HL-60 cell differentiation to granulocytes. ${ }^{36}$ Moreover, we have been able to demonstrate the relationship between differentiation mechanisms involving PKA and PKC in uninduced and differentiating HL-60 cells. ${ }^{37}$ Data exists that the basal activity of PKC prevents the occurrence of apoptosis in HL-60 cells and MOLT-4 cells. ${ }^{39,40}$ In contrast, IPC-81 myeloid leukemia cells undergo apoptosis in response to agents that elevate intracellular cAMP levels. ${ }^{41}$ It has also been shown that activation of the conventional isoform of PKC during differentiation of myeloid U937 cells causes apoptosis of differentiating cells. ${ }^{42}$ 
Earlier we have shown that modulation of PKA or PKC activity causes changes of the level of HL-60 cell differentiation induced by RA and dbcAMP. The present study was undertaken (1) to elucidate the contribution of protein kinase PKA and PKC in promoting or suppressing apoptosis in proliferating and differentiating HL-60 cells; (2) to estimate the correlation between the number of differentiating and apoptotic cells at distinct stages in a differentiating HL-60 cell population and (3) to ascertain at which phase of the cell cycle (G1 or G2/M) cell arrest is more preferable for initiation of apoptosis. Our findings demonstrate that the apoptotic programme of proliferating myeloid cells can be induced by suppression of PKC activity, and that the functional maturity of differentiating $\mathrm{HL}-60$ cells is not always necessary for triggering an apoptotic programme.

\section{Results}

\section{Inhibition of PKC or PKA promotes apoptosis in proliferating HL-60 cells at a different extent}

HL-60 cells were exposed to two highly specific inhibitors of PKC (calphostin C and GF 109203X) and an inhibitor of PKA (H89). Calphostin $C$ interacts with the regulatory domain of PKC by competing at the binding site of diacylglycerol. GF 109203X interacts with ATP-binding site of PKC. The effective concentrations of each inhibitor causing $50 \%$ maximal response $(E C 50)^{13}$ were used in our experiments. Quantitative analysis of DNA fragmentation was performed after $72 \mathrm{~h}$ of treatment and the appearance of apoptosis was monitored on days 6 and 9 in the proliferating cell cultures. The effects of these protein kinase inhibitors on cell viability were determined by trypan blue exclusion. None of the agents tested potentiated the suppression of cell growth or viability during the period of 6 days. The decrease in cell viability $(<20 \%)$ was found after co-incubation of the proliferating cells with inhibitors for 9 days (data not shown). Also, the relationship between decrease in cell viability and increase in the number of apoptotic cells was noted.

DNA fragmentation (diphenylamine assay) induced by inhibitors of protein kinase after 3 days of co-incubation was associated with appearance of cells with morphological characteristics of apoptosis (acridine orange/ethidium bromide staining) on day 6 (Table 1). Both inhibitors of PKC promoted extensive DNA fragmentation (37 and 39\%) as tested after $72 \mathrm{~h}$. The effect of PKA inhibitor, H89, on DNA fragmentation (23\%) was not as potent as of PKC inhibitors. Qualitative analysis of DNA fragmentation was performed using agarose gel electrophoresis and the results were consistent with the quantitative studies of DNA fragmentation (Figure 1, Table 1).

During $72 \mathrm{~h}$ of treatment with drugs the cell viability remained high (95-97\%). In order to assess relationship between cell viability and apoptosis we stained cells in two parallel aliquots from the same cell culture with (1) acridine orange/ethidium bromide (AO/ET) or (2) trypan blue (TB). This technique allows to identify the cells with apoptotic characteristics among live cells (the membrane of latter is not damaged and ethidium bromide cannot enter the cell).
These cells do not stain with trypan blue, but green apoptotic bodies are visible after AO/ET staining, whereas apoptotic bodies in dead cells stain red. Thus, e.g. on the sixth day of differentiation (Table 1), after treatment with PKA inhibitor, $\mathrm{H} 89$, the cells were viable $(95 \%$, TB exclusion). However, based on AO/ET staining $19 \%$ of the cells in aliquots tested had morphological features of apoptotic cells. This included $5 \%$ of the cells, which were stained red by AO/ET, and were considered as dead cells.

Table 1 Effects of protein kinase inhibitors on the induction of apoptosis in proliferating HL-60 cells

\begin{tabular}{lccc}
\hline Treatment & $\begin{array}{c}\text { Apoptotic } \\
\text { cells (\%) }\end{array}$ & $\begin{array}{c}\text { Viability } \\
\text { (\%) }\end{array}$ & $\begin{array}{c}\text { DNA } \\
\text { fragmentation (\%) }\end{array}$ \\
\hline $50 \mathrm{nM} \mathrm{H89}$ & $19 \pm 1.3$ & $95 \pm 2.3$ & $23 \pm 2.4$ \\
$100 \mathrm{nM}$ calphostin C & $26 \pm 3.4$ & $98 \pm 1.7$ & $37 \pm 3.1$ \\
$25 \mathrm{nM} \mathrm{GF} \mathrm{109203X}$ & $25 \pm 4.2$ & $97 \pm 2.3$ & $39 \pm 2.3$ \\
Control & $8 \pm 3.5$ & $95 \pm 3.3$ & $9 \pm 3.4$ \\
\hline
\end{tabular}

Cells were incubated with the indicated protein kinase inhibitor for 6 days. DNA fragmentation was determined (diphenylamine assay) on day 3 of treatment. Apoptotic cells in preparations stained with acridine orange/ethidium bromide were evaluated using fluorescence microscopy on day 6 . Cell viability was assayed by exclusion of trypan blue on day 6 . Results represent means of three separate experiments

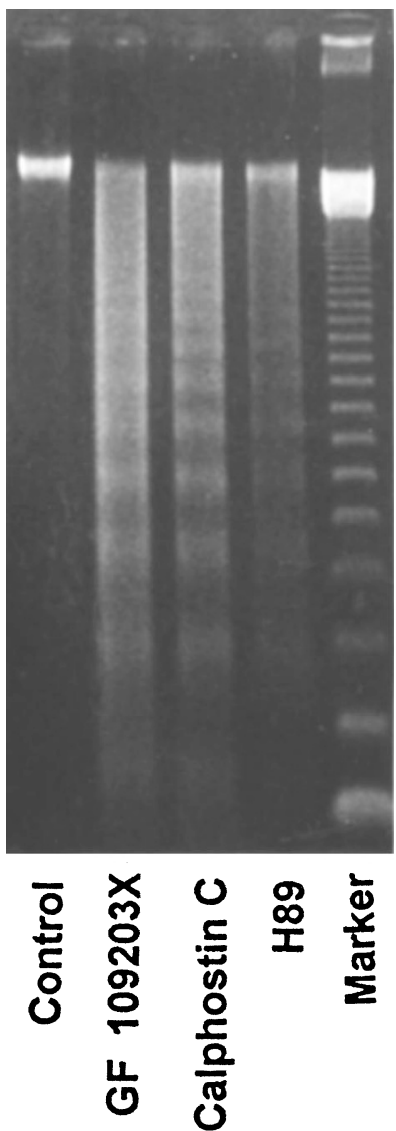

Figure 1 Induction of DNA fragmentation by protein kinase inhibitors in proliferating HL-60 cells. Control cells were treated with protein kinase inhibitors: $20 \mathrm{nM}$ GF $109203 \mathrm{X}, 100 \mathrm{nM}$ calphostin $\mathrm{C}$ and $50 \mathrm{nM} \mathrm{H} 89$. DNA was extracted after $72 \mathrm{~h}$ of treatment with inhibitor and electrophoresed in $1.5 \%$ agarose gel. Marker is the 123 bp DNA ladder 
The remaining cells (14\%) were considered alive since their apoptotic bodies were stained green by AO only. Therefore, the total population of viable cells in the sample $(95 \%)$ included the live cells with apoptotic characteristics (14\%), as calculated above.

It should be noted that cell death in control culture (no inhibitors used) on day 9 was $73 \%$ (data not shown). This was associated with DNA damage and morphological changes characteristic to apoptosis caused by the increased density of the cells in culture and acidification of the medium.

\section{Apoptosis is associated with RA- and dbcAMP-induced differentiation}

Granulocytic differentiation of HL-60 cells was induced by dbcAMP $(350 \mu \mathrm{M})$ or RA $(500 \mathrm{nM})$. These inducers of differentiation at the concentrations used typically results in a reduction of cell growth $(25-30 \%)$ and viability (20$30 \%)^{36}$

In the present study both, dbcAMP and RA, induced cell differentiation in a dose-dependent manner. A dosedependent increase of granulocytic differentiation was associated with an increase of apoptotic cells in the population (Figure 2). These cells can be recognised by the appearance of nuclear condensation, a marked decrease in cellular volume and formation of apoptotic bodies at the sixth day after induction of differentiation. The maximal concentrations of both inducers (500 $\mu \mathrm{M}$ dbcAMP and $700 \mathrm{nM}$ RA) used in experiments resulted in an increase of the number of differentiated cells by $50 \%$ at day 4. Addditional $48 \mathrm{~h}$ of co-incubation of the cells with inducers of differentiation resulted in apearance of apoptotic cells in the cultures $(29 \%$ in dbcAMP-induced and $46 \%$ in RA-induced) (Figure 2). In RA-induced differentiating cells internucleosomal DNA fragmentation was clearly visible after 48 and $72 \mathrm{~h}$ of induction (Figure $3 \mathrm{~A})$. The fraction of PI stained cells, which contained reduced DNA content due to degradation, appeared to be at the left side of the $\mathrm{G} 1$ peak on a histogram and was increasing during first 3 days of differentiation in a timedependent manner (Figure 3B). These observations indicate that in dbcAMP- or RA-induced, into granulocytes differentiating HL-60 cell population part of the cells undergo apoptosis and this event is triggered not later than $48 \mathrm{~h}$ after induction of differentiation.

\section{Effects of PK inhibitors on HL-60 cell differentiation and subsequent apoptosis}

Further studies were undertaken to determine whether inhibitors of PKC or PKA could affect RA-induced (500 nM) granulocytic cell differentiation and differentiation-accompanying apoptotic events. HL-60 cells were exposed to two highly specific inhibitors of PKC, calphostin C and GF 109203X, and the inhibitor of PKA, H89. The EC 50 values of all inhibitors ${ }^{13}$ used in our experiments had no effect on RAinduced cell viability (data not shown). The data presented in Figure 4 indicates that after 4 days of co-incubation of HL-60 cells with RA, $37 \%$ of cells were differentiated, while $26 \%$ of the
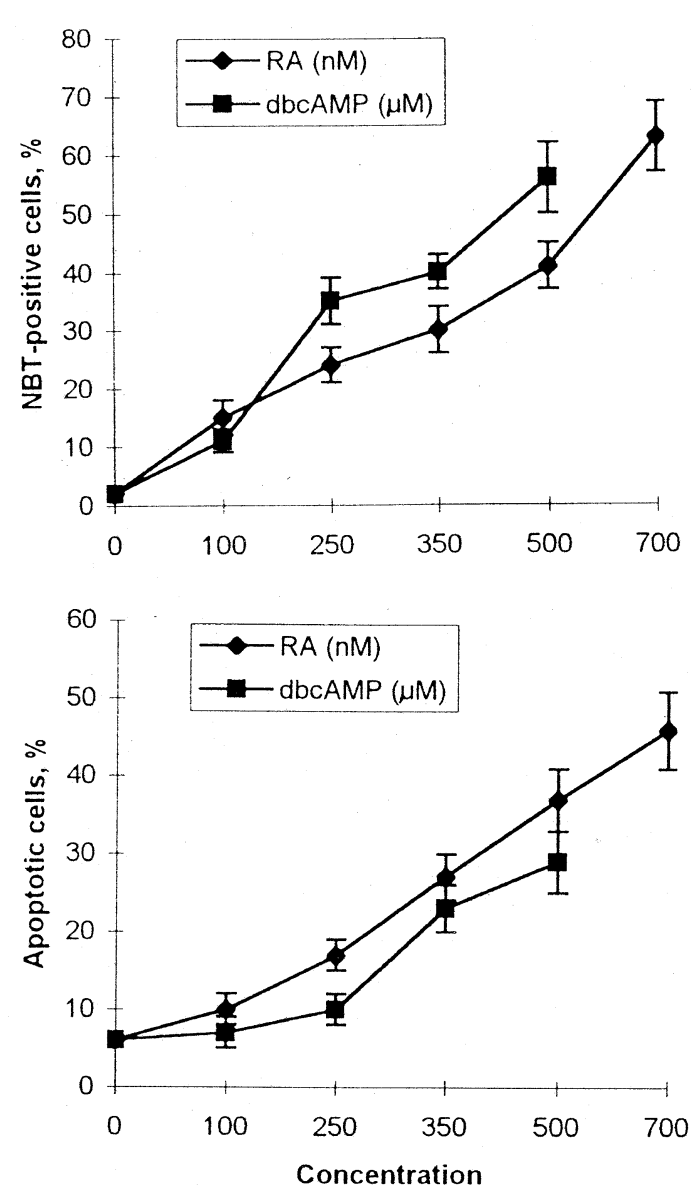

Figure 2 RA and dbcAMP potentiate apoptosis in HL-60 cell culture. Cells $\left(4 \times 10^{5} \mathrm{cell} / \mathrm{ml}\right)$ were incubated with different concentrations of RA $(\mathrm{nM})$ and dbcAMP $(\mu \mathrm{M})$. Cell differentiation was determined by NBT reducing ability on day 4. Apoptotic cells were determined by morphological evidence in preparations stained with acridine orange/ethidium bromide on day 6. Data represent mean \pm S.E.M. of three separate experiments

cells within same population had fragmented DNA at day 3.

Both the inhibitors of PKC (calphostin $C$ and GF 109203X) potentiated RA-mediated cell differentiation and DNA fragmentation with respect to untreated control, while the PKA inhibitor (H89) suppressed cell differentiation and did not alter the DNA fragmentation (Figure 4). The electrophoretic analysis of DNA (Figure 5) obtained from HL-60 cells after 3 days of co-incubation with RA and PKC or PKA inhibitors confirmed the results of DNA fragmentation presented in Figure 4. Thus, the results revealed that correlation between changes in the number of differentiated cells induced by RA and apoptotic cells in this differentiating HL-60 cell population can be altered. To check this phenomenon more precisely, RA- and dbcAMP-mediated differentiation of HL-60 cells have been modulated by using different concentrations of PKC inhibitor, calphostin $\mathrm{C}$, and PKA inhibitor, H89 (Figures 6 and 7). The correlation between the number of differentiated and apoptotic cells was found during RA-induced differentiation when cells were exposed to calphostin C. dbcAMP-mediated differentiation was suppressed by calphostin C to $43 \%$, while the 
number of apoptotic cells was increased up to $147 \%$, as compared to the apoptotic cells from the control population (Figure 6). PKA inhibitor, H89, suppressed both RA- and
dbcAMP-mediated differentiation, however, the number of apoptotic cells diminished only in the case of dbcAMP, while in RA-differentiated cell population it remained at the

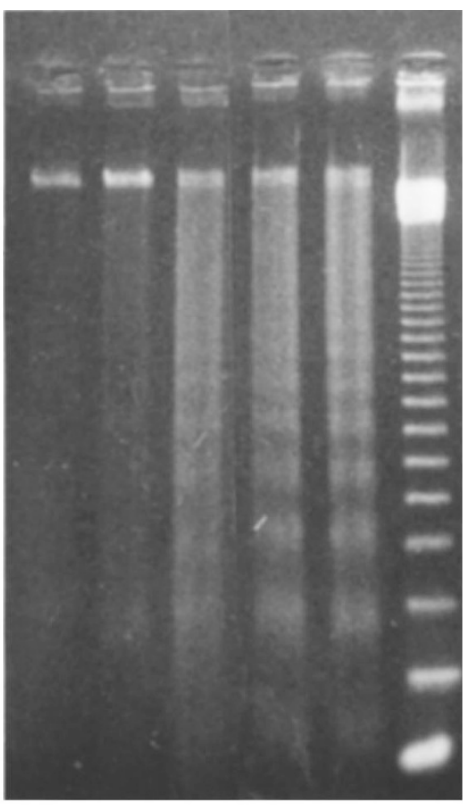

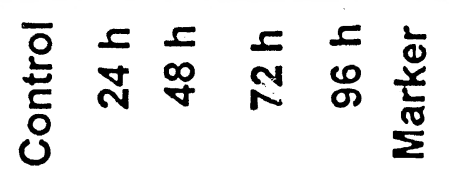

B

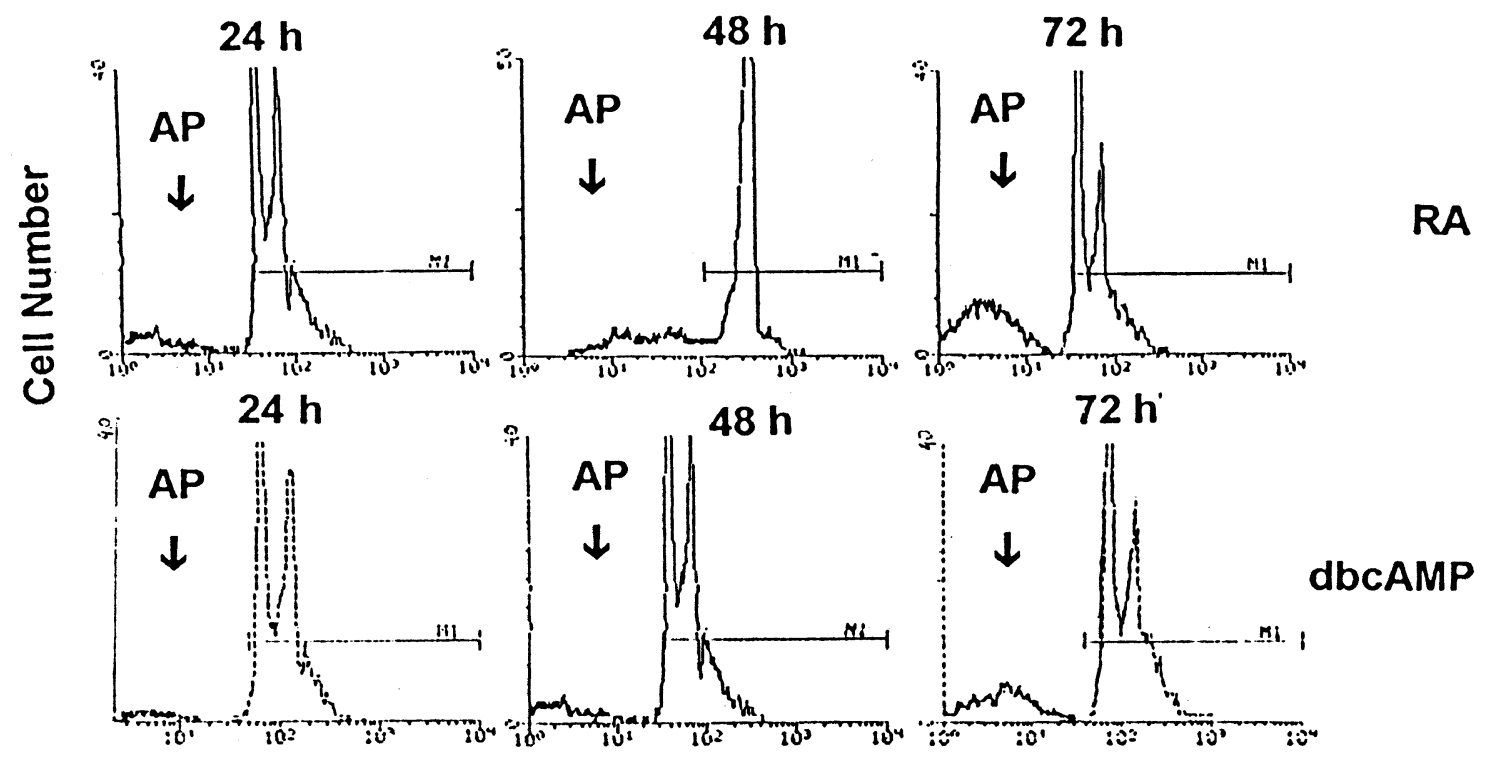

\section{DNA Content}

Figure 3 Time course of DNA fragmentation during RA-induced differentiation and flow cytometry analysis of cell cycle distribution in HL-60 differentiating cells (A) HL-60 cells $\left(4 \times 10^{5}\right.$ cells $\left./ \mathrm{ml}\right)$ were treated with $500 \mathrm{nM} \mathrm{RA}$ for 4 days. DNA was extracted daily during $96 \mathrm{~h}$ of induction and electrophoresed in $1.5 \%$ agarose gel. Marker is the 123 bp DNA ladder. (B) Representative example of flow cytometric analysis of HL-60 cells treated with $500 \mathrm{nM}$ RA and $350 \mu \mathrm{M}$ dbcAMP during $72 \mathrm{~h}$. An hypodiploid peak (subG1) represents the amount of apoptotic cells (AP). The percentages of apoptotic nuclei were for RA after 24,48 and $72 \mathrm{~h}$ of induction $12.2 \pm 0.3 \%, 21.0 \pm 3.3 \%, 28.2 \pm 2.5 \%$, respectively; for dbcAMP $-11.9 \pm 1.2 \%, 19.6 \pm 2.7 \%, 24.2 \pm 3.6 \%$, respectively. Results represent means of three separate experiments 
same level (Figure 7). The growth of differentiating HL-60 cells was suppressed with various concentrations of calphostin $\mathrm{C}$ or $\mathrm{H} 89$ on day 4 (Figures 6 and 7). Protein kinase inhibitors caused a similar degree of growth inhibition as compared to the drug untreated control cells (73\% for RA and $77 \%$ for dbcAMP). This indicates the cytostatic action of protein kinase inhibitors.

More evidence indicating that apoptosis can be separated from differentiation has been obtained in experiments in which level of differentiation was modulated by the suppression of PKC activity in proliferating HL-60 cells $24 \mathrm{~h}$ before induction of differentiation. In these experiments (1) the cells were pretreated with calphostin C for $24 \mathrm{~h}$, washed, and medium supplemented with RA or dbcAMP instead of calphostin C was added ( $-24-0 \mathrm{~h})$; (2) after $24 \mathrm{~h}$ pretreatment with calphostin $C$ the cells were subsequently induced to differentiate with RA or dbcAMP in the presence of calphostin C (-24-96 h); (3) calphostin C was added along with one of the inducers of differentiation $(0-96 \mathrm{~h})$. The results presented in Figure 8 clearly demonstrate drastic differences in RA-induced cell differentiation after pretreatment of the cells with calphostin $C$, i.e. the number of differentiated cells was diminished to $60-75 \%(-24-0 \mathrm{~h}$,
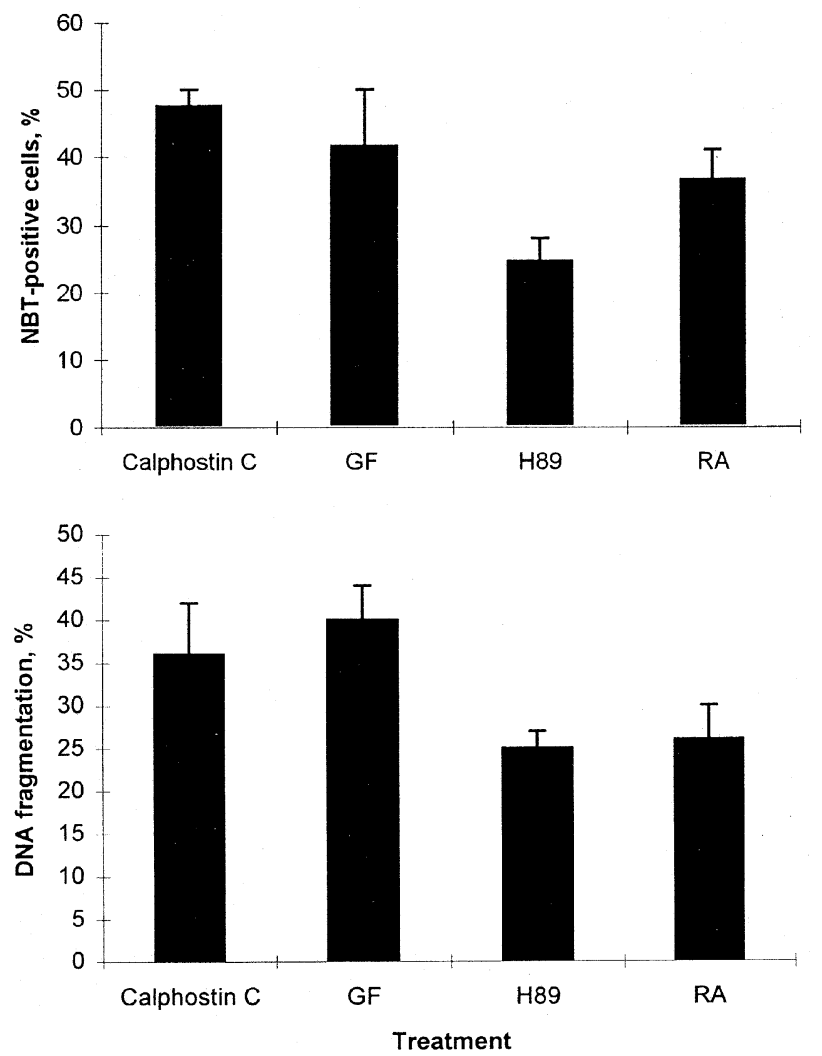

Figure 4 Effects of protein kinase inhibitors on RA-mediated HL-60 cel differentiation and induction of DNA fragmentation. Cells were incubated with $500 \mathrm{nM}$ RA and protein kinase inhibitors: $100 \mathrm{nM}$ calphostin C, $20 \mathrm{nM}$ GF 109203X and $50 \mathrm{nM} \mathrm{H89}$. Cell differentiation was determined on day 4 after induction by NBT reducing ability and expressed as mean percentages of the viable cell number. Samples for quantitation of DNA fragmentation (diphenylamine assay) were taken on day 3 after induction and results were expressed as the percentage of total DNA. Results represent a mean \pm S.E.M. of three separate experiments
$-24-96 \mathrm{~h})$ or increased to $145 \%(0-96 \mathrm{~h})$ as compared to the control differentiating cells growing in the absence of calphostin C. However, in all of the above mentioned cell populations treated with calphostin $\mathrm{C}$ the number of apoptotic cells was increased to 145 to $135 \%$, respectively. In the dbcAMP-induced cell culture any experimental trial to inhibit PKC resulted in the suppression of differentiation to $50-55 \%$, while the number of apoptotic cells was always increased (Figure 8). The fact that apoptosis was induced by PKC inhibitors, calphostin C or GF 109203X, in proliferating cells, and that PKC inhibition before induction of differentiation caused a higher level of apoptosis when compared to PKC inhibition during differentiation, suggests that a fraction of the apoptotic cells arise from proliferating cells or cells being at early stages of differentiation.

\section{Effects of RA pretreatment on dbcAMP-induced differentiation and apoptosis, and effects of dbcAMP pretreatment on RA-induced differentiation and apoptosis}

In our previous study ${ }^{37}$ we have shown that the pretreatment of HL-60 cells with dbcAMP for the duration

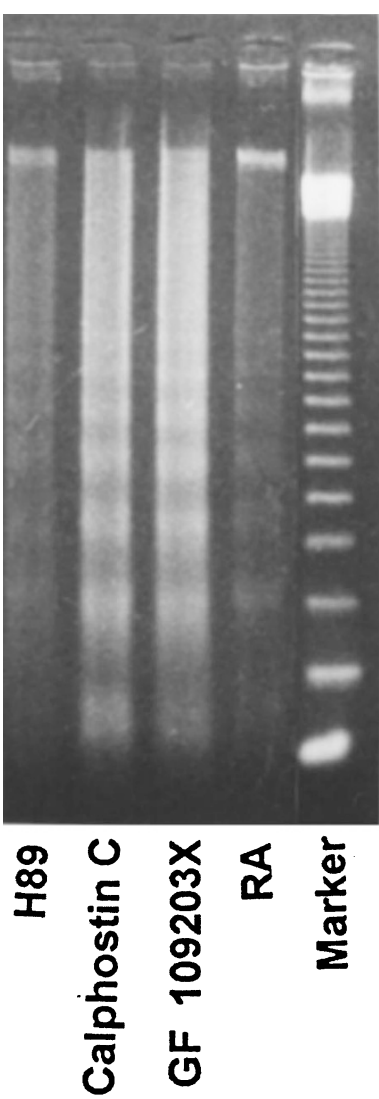

Figure 5 Induction of DNA fragmentation by protein kinase inhibitors in differentiating HL-60 cells. Cells were induced by $500 \mathrm{nM}$ RA and treated with protein kinase inhibitors: $100 \mathrm{nM}$ calphostin C, $20 \mathrm{nM}$ GF $109203 \mathrm{X}, 50 \mathrm{nM} \mathrm{H} 89$. DNA was extracted after $72 \mathrm{~h}$ of co-treatment and electrophoresed in $1.5 \%$ agarose gel. Marker is the $123 \mathrm{bp}$ DNA ladder 
of one cell cycle only strongly potentiated RA-mediated differentiation, while the pretreatment with RA suppressed dbcAMP-mediated differentiation. The aim of the present
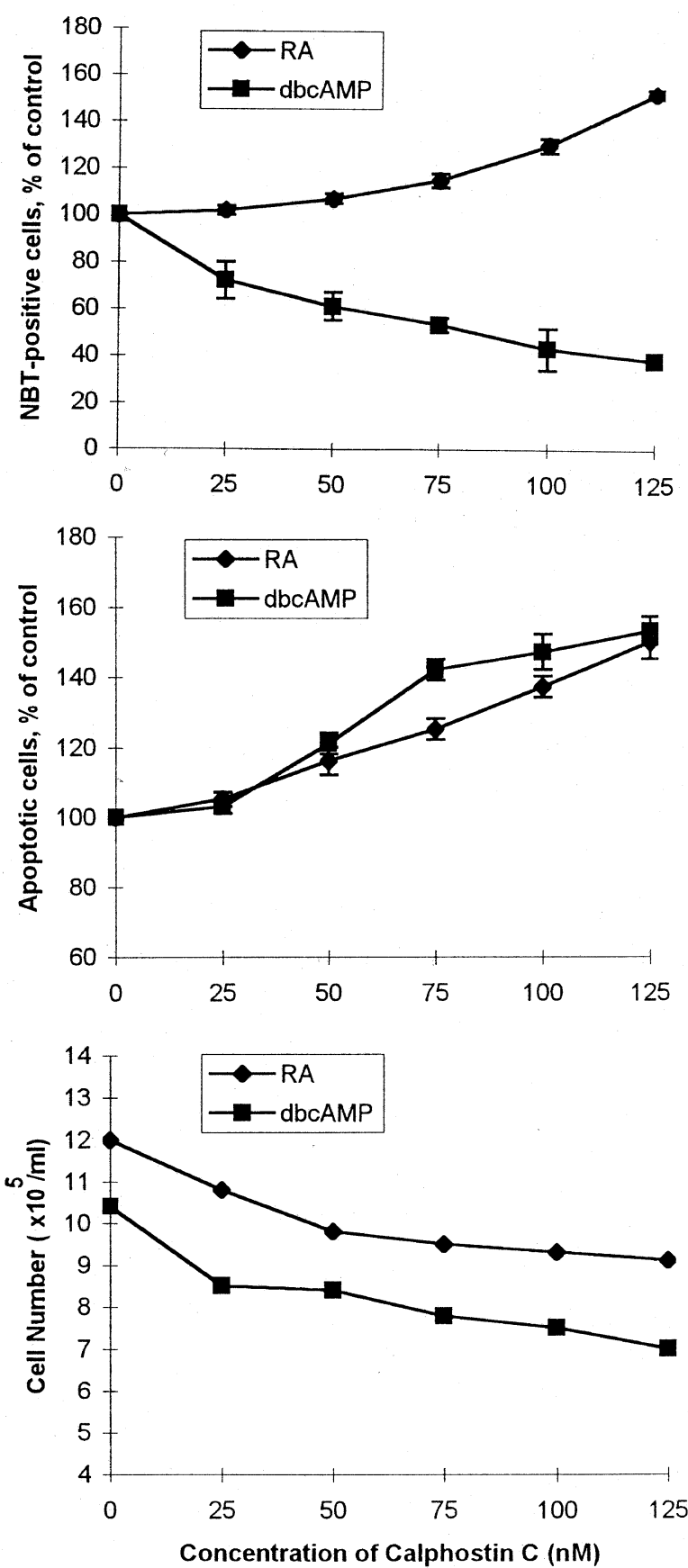

Figure 6 Effects of various concentrations of PKC inhibitor calphostin $C$ on $\mathrm{RA}$ and dbcAMP-mediated $\mathrm{HL}-60$ cell growth, differentiation and apoptosis. Cells $\left(4 \times 10^{5}\right.$ cells $\left./ \mathrm{ml}\right)$ were incubated with $500 \mathrm{nM}$ RA or $350 \mu \mathrm{M}$ dbcAMP and various concentrations of calphostin $\mathrm{C}$. Cell differentiation was determined on day 4 after induction by NBT reducing ability. Apoptotic cells were determined by morphological evidence on day 6 . Data are expressed in relation to that of control (untreated with inhibitor) and presented as a mean + S.E.M. of six separate experiments. Cell growth curves on day 4 are representative examples from four separate experiments in which variation of the data was less than $+10 \%$ study was to assess the effects of RA- or dbcAMPpretreatment on modulation of apoptosis in a differentiating population of dbcAMP- or RA-induced cells, and whether
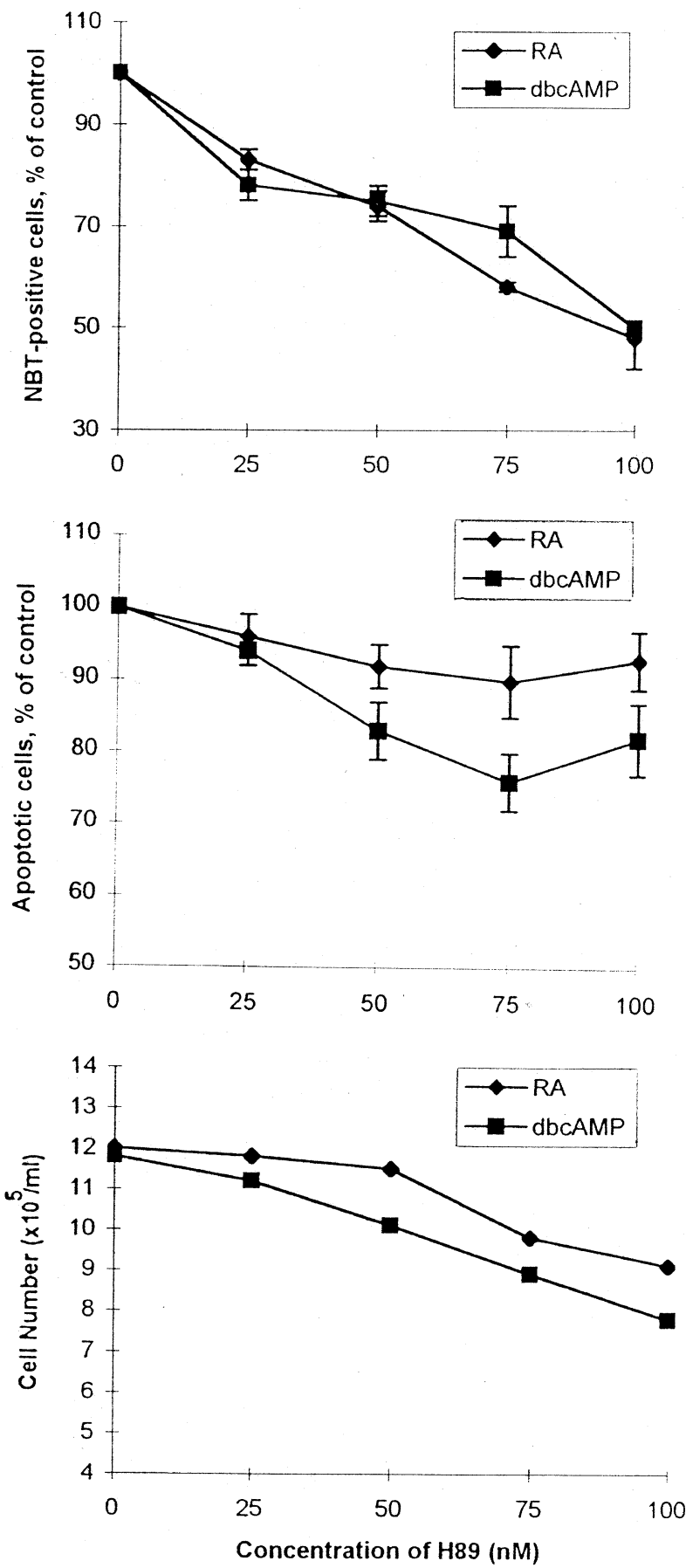

Figure 7 Effects of various concentrations of PKA inhibitor H89 on RA- and dbcAMP-mediated HL-60 cell growth, differentiation and apoptosis. Cells $\left(4 \times 10^{5}\right.$ cells $\left./ \mathrm{ml}\right)$ were incubated with $500 \mathrm{nM}$ RA and $350 \mu \mathrm{M}$ dbcAMP and various concentrations of $\mathrm{H} 89$. Cell differentiation was determined on day 4 after induction by NBT reducing ability. Apoptotic cells were determined by morphological evidence on day 6 . Data are expressed in relation to that of control (untreated with inhibitor) and presented as a mean \pm S.E.M. of six separate experiments. Cell growth curves on day 4 are representative examples from four separate experiments in which variation of the data was less than $+10 \%$ 
apoptotic events correlate with distinct levels of differentiation. The obtained data indicate that there was no such correlation at all (Figure 9): (1) pretreatment with RA slightly altered dbcAMP-induced differentiation (by 20\%), but, on the contrary, significantly promoted apoptosis depending on RA concentration (700 nM); (2) pretreatment with dbcAMP highly promoted RA-mediated differentiation $(120-180 \%)$ and did not cause changes in the level of apoptosis.

\section{Cell cycle analysis}

To examine changes in the cell cycle distribution associated with cell differentiation or apoptosis, the flow cytometric analysis of HL-60 cells treated with different agents or their combinations has been performed. The data shown in Table 2 demonstrate the results of the cell cycle analysis obtained after 24, 48 and $72 \mathrm{~h}$ of exposure of HL-60 cells to (1) inducers of differentiation (RA or dbcAMP); (2) calphostin C and its combination with one of the inducers or (3) RA after pretreatment with dbcAMP or vice versa.

The data presented here revealed two general groups of cell cultures which differ in the ratio of cells arrested in G1 and G2/M phases of the cell cycle (Table 2, A and B, bold
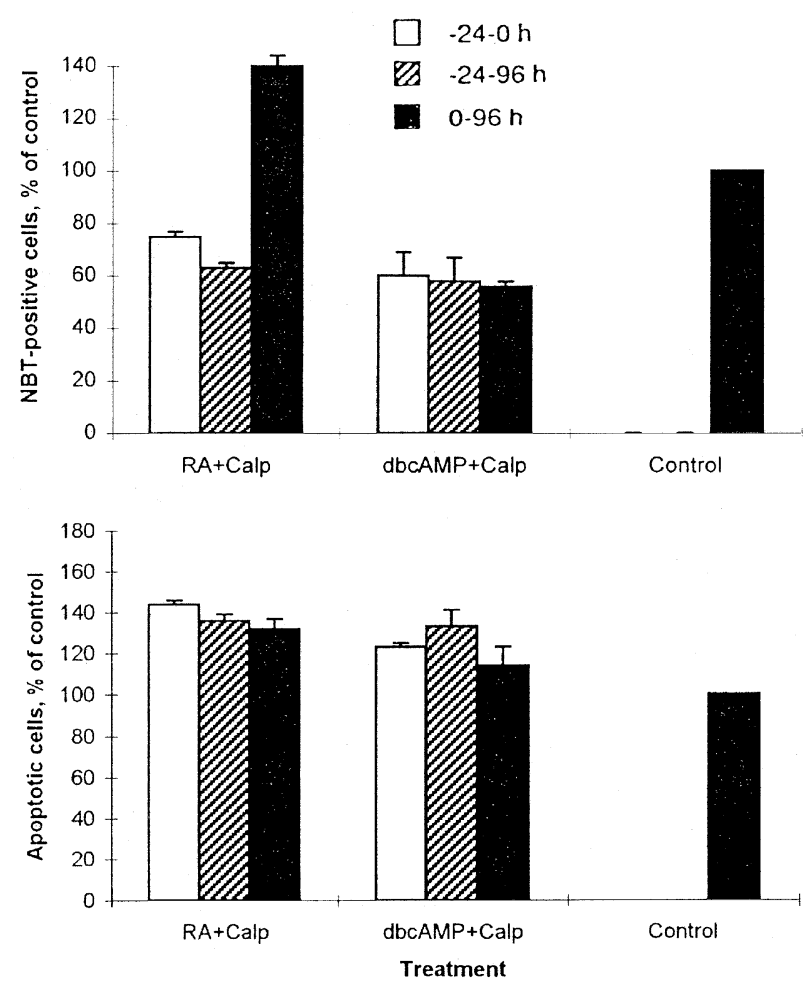

Figure 8 Effects of PKC inhibitor, calphostin $C$ on the level of differentiation and apoptosis of $\mathrm{HL}-60$ cell. Cells $\left(4 \times 10^{5}\right.$ cells $\left./ \mathrm{ml}\right)$ were induced with $500 \mathrm{nM}$ RA or $350 \mu \mathrm{M}$ dbcAMP and cultivated with PKC inhibitor, $100 \mathrm{nM}$ calphostin $\mathrm{C}$ during different time shown as bars: $(-24-96 \mathrm{~h})$ pretreatment before induction of differentiation, $(0-96 \mathrm{~h})$ full time of differentiation, $(-24-96 \mathrm{~h})$ pretreatment and full time of differentiation. In control experiments only RA was added to the culture medium. The percentages of differentiated and apoptotic cells are given as a percentage of control cells. Results represent mean \pm S.E.M. of three separate experiments numbers). In group A obvious tendency in significant, timedependent increase in the fraction of G1 phase during cell differentiation (from $38-44 \%$ to $65-78 \%$ ) was noted. After the same period of time the number of cells in the G2/M phase was slightly decreased (by $3-8 \%$ ). Our previous results reported above showed that cell differentiation was more pronounced than apoptosis in these cell cultures. On the contrary, data presented in group B (Table 2) indicates that under these experimental conditions the higher number of apoptotic cells was present in cell cultures when compared to the number of differentiated cells. In these populations the

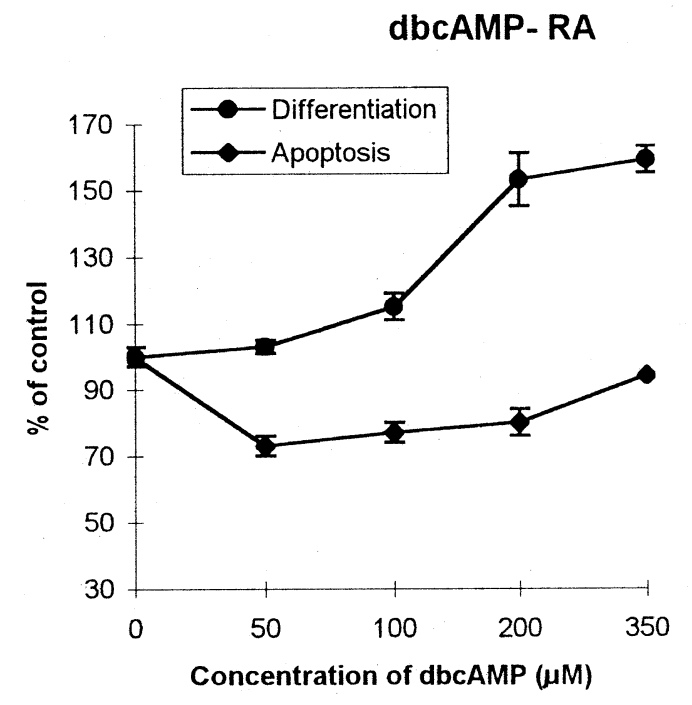

RA - dbcAMP

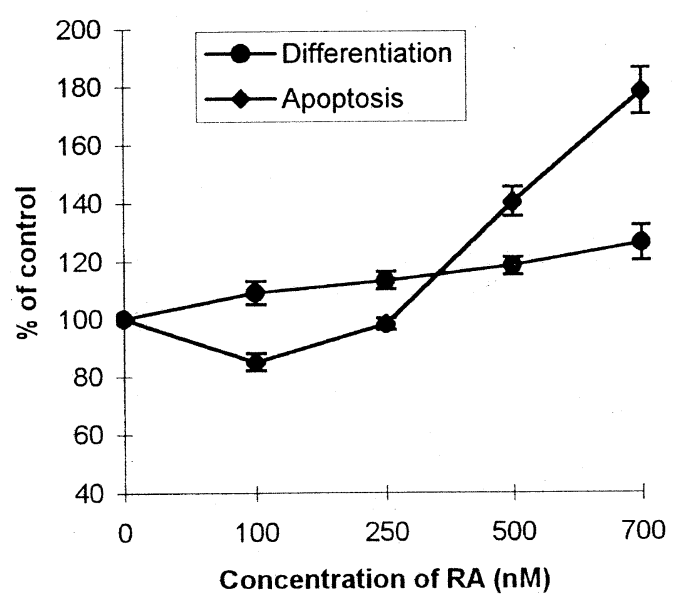

Figure 9 Effects of dbcAMP or RA pretreatment on RA-induced or dbcAMPinduced HL-60 cell differentiation and apoptosis. HL-60 cells $\left(4 \times 10^{5} \mathrm{cells} / \mathrm{ml}\right)$ were pretreated with different concentrations of RA or dbcAMP for $24 \mathrm{~h}$ before the induction of differentiation, after the drugs were washed out and the cells were incubated with $350 \mu \mathrm{M}$ dbcAMP or $500 \mathrm{nM} \mathrm{RA}$, respectively for a further $96 \mathrm{~h}$. Cell differentiation was determined on day 4 after induction by NBT reducing ability. Apoptotic cells were determined by morphological evidence on day 6 . The number of differentiated and apoptotic cells were expressed as a percentage of control cells (without pretreatment). Results represent a mean \pm S.E.M. of three separate experiments 
Table 2 Flow cytometric analysis of the cell cycle distribution in HL-60 cells

\begin{tabular}{|c|c|c|c|c|}
\hline \multirow[b]{4}{*}{ Treatment } & \multicolumn{4}{|c|}{ Time of treatment $(\mathrm{h})$} \\
\hline & 24 & 48 & 72 & 72 \\
\hline & \multicolumn{3}{|c|}{ Cell cycle distribution (\%) } & \\
\hline & G1/S/G2+M & G1/S/G2+M & G1/S/G2+M & subG1 \\
\hline $\begin{array}{l}\text { A } \\
\text { RA } \\
\text { dbcAMP } \\
\text { RA+Clp } \\
\text { dbcAMP } \rightarrow \text { RA }\end{array}$ & $\begin{array}{l}38 / 43 / 19 \\
42 / 38 / 20 \\
50 / 28 / 22 \\
44 / 34 / 22\end{array}$ & $\begin{array}{l}56 / 31 / 13 \\
55 / 20 / 25 \\
66 / 19 / 15 \\
60 / 22 / 18\end{array}$ & $\begin{array}{l}65 / 23 / 12 \\
75 / 13 / 12 \\
78 / 8 / 14 \\
65 / 17 / 17\end{array}$ & $\begin{array}{l}28 \\
24 \\
48 \\
46\end{array}$ \\
\hline $\begin{array}{l}\text { B } \\
\text { Clp } \\
\text { dbcAMP+Clp } \\
\text { Clp } \rightarrow \text { RA } \\
\text { Clp } \rightarrow \text { dbcAMP } \\
\text { RA } \rightarrow \text { dbcAMP }\end{array}$ & $\begin{array}{l}42 / 36 / 22 \\
51 / 22 / 27 \\
42 / 38 / 20 \\
41 / 38 / 21 \\
41 / 40 / 19\end{array}$ & $\begin{array}{l}38 / 34 / 28 \\
61 / 13 / 26 \\
49 / 32 / 19 \\
48 / 29 / 23 \\
66 / 18 / 16\end{array}$ & $\begin{array}{l}38 / 39 / 23 \\
65 / 15 / 20 \\
52 / 26 / 22 \\
37 / 33 / 30 \\
55 / 19 / 26\end{array}$ & $\begin{array}{l}43 \\
45 \\
40 \\
42 \\
64\end{array}$ \\
\hline Control & $39 / 51 / 9$ & $42 / 47 / 10$ & $46 / 45 / 10$ & 12 \\
\hline
\end{tabular}

HL-60 cells were treated: (1) with $500 \mathrm{nM}$ RA or $350 \mu \mathrm{M}$ dbcAMP; (2) with $100 \mathrm{nM}$ calphostin $\mathrm{C}(\mathrm{Clp})$ alone or in combination with RA or dbcAMP (RA+Clp, dbcAMP+Clp); with RA or dbcAMP after pretreatment with calphostin $C$ for $24 \mathrm{~h}$ $(\mathrm{Clp} \rightarrow \mathrm{RA}, \mathrm{Clp} \rightarrow \mathrm{dbcAMP})$; (3) with $500 \mathrm{nM}$ RA after pretreatment with $350 \mu \mathrm{M}$ $\mathrm{dbcAMP}$ for $24 \mathrm{~h}(\mathrm{dbcAMP} \rightarrow \mathrm{RA})$ or with $350 \mu \mathrm{M}$ dbcAMP after pretreatment with $700 \mathrm{nM}$ RA for $24 \mathrm{~h}$ (RA $\rightarrow$ dbcAMP). The cell cycle phase distribution of $\mathrm{HL}-60$ cells during $72 \mathrm{~h}$ of induction was determined from DNA frequency distribution histograms of PI stained cells using CellFITT program (Becton-Dickinson). The per cent of apoptotic cells (subG $)_{1}$ ) was established from respective histograms of PI stained cells following incubation in hypotonic citrate buffer using Lysisll program (log scale). Each value is the average of two or more independent experiments with similar results

per cent of cells in the G2/M phase was approximately twofold increased (20-30\%) compared to control cells $(10 \%)$ and was higher in cell cultures from group A (12-17\%) during $72 \mathrm{~h}$ of treatment. The per cent of cells arrested in the G1 phase in group B remained without significant changes.

As shown in Table 2, $12 \%$ of the cells in growing control population were with apoptotic characteristics (subG1 peak) after $72 \mathrm{~h}$, while in differentiating cell cultures apoptotic subG1 peak was increased to $24-48 \%$ (group A) or to $40-64 \%$ (group B) after the same period of time. It should be pointed out that calphostin $\mathrm{C}$-induced apoptosis resulted in appearance of cells with a significantly enhanced hypopdiploid peak (about 46\%, bold numbers). Also, in RA-pretreated dbcAMP-induced cell culture subG1 peak was markedly increased $(64 \%)$ in comparison to the opposite combination of the treatment (46\%).

It is important to note that flow cytometric data presented in Table 2 consider very closely with the results of DNA cleavage identified by DNA fragmentation assay (Table 1, Figure 4).

Thus, the quantitative analysis of the cell cycle distribution ( $\mathrm{G} 1$ versus $\mathrm{S}$ versus $\mathrm{G} 2 / \mathrm{M}$ ) clearly demonstrates that there is the correlation between the number of cells arrested in G1 or G2/M phase of the cell cycle and differentiation or apoptosis, respectively.

\section{Discussion}

In order to improve the strategy for therapy of leukemias, it is of interest to know the regulatory mechanisms gearing granulocytic differentiation and the subsequent apoptosis. It has been reported that HL-60 cells in vitro differentiated to granulocytes, like their normal counterparts in blood die via apoptosis. ${ }^{10,12,48}$ However, more recent studies demonstrate that actively proliferating cells can be triggered to apoptosis by modulation of the activities of PKC and PKA ${ }^{13,41,49}$ and the differentiating cells may die via apoptosis at distinct stages of differentiation as well. ${ }^{50}$ Moreover, there are indirect evidences that differentiation and apoptosis are separately regulated entities. ${ }^{42,51,52}$ In addition, some studies have shown that induction of differentiation mediates increased resistance of cells to apoptosis-inducing agents. ${ }^{53-55}$ This phenomenon can enhance an already induced apoptotic program in leukemia cells. ${ }^{13,56,57}$

In this study we have shown that apoptotic events can be partially dissociated from differentiating cells in a HL-60 leukemia cell population induced to differentiate to granulocytes by RA and dbcAMP. This can be achieved by modulation of the PKA and PKC activities in proliferating cells before induction of differentiation or in differentiating cells at the early stages of differentiation as (1) when the activity of PKC is inhibited during dbcAMP-mediated differentiation (Figure 6) or the activity of PKA is suppressed during RA-mediated differentiation (Figure 7); (2) when the activity of PKC are inhibited before induction of differentiation, regardless of the inducer used or (3) when HL-60 cells are exposed for one cell cycle to dbcAMP and then differentiate in the presence of RA or vice versa. The latter case, in our opinion, is interesting and promising for differentiation therapy of leukemias because dbcAMP drastically potentiates RA-mediated differentiation and does not raise the number of apoptotic cells. It is of interest also that in some cases the number of apoptotic cells can exceed the number of differentiated ones in population, e.g. in both RA- and dbcAMP-induced differentiating cells pretreated with calphostin $C$, or dbcAMPinduced differentiating cells pretreated with calphostin $C$, or dbcAMP-induced differentiating cells pretreated with RA. Collectively, these data clearly demonstrate that in vitro differentiated mature granulocytes are not single source of apoptotic cells. Potentially there could be three sources of apoptotic cells in a differentiating promyelocytic leukemia HL-60 cell population: (1) proliferating cells resistant to inducers of differentiation but highly sensitive to all metabolic consequences caused by the inducer; (2) differentiating cells that are not capable of adjusting themselves to metabolic changes caused by inducers at distinct stages of differentiation and (3) the differentiated mature granulocytes dying due to ageing. Substantial evidence exist demonstrating that proliferating somatic cells contain an apoptotic program (for review see ${ }^{58}$ ). Short exposure of $\mathrm{HL}-60$ cells to various concentrations of PKC inhibitor promotes these cells to initiate apoptosis. ${ }^{13-59}$ In the case of RA-mediated differentiation the appearance of apoptotic cells by induction of differentiation can be explained by isomerization of RA to its isomer 9-cis RA. RA binds only to RAR receptors which is sufficient to induce differentiation, while 9-cis RA activates both classes of receptors-RAR and $R X R$, and ligand activation of $R X R$ receptor is a major cause of induction of apoptosis. ${ }^{14}$ The exposure of HL-60 
cells to RA has been shown to cause an altered activity of some isoforms of $\mathrm{PKC} .^{22,29}$ Also, the inhibition of the activity of PKC during the commitment stage markedly increases the level of differentiated HL-60 cells induced by RA. $^{36}$ This phenomenon can enhance an already induced apoptotic program. ${ }^{13}$

Mature neutrophils in blood have a short life span and die via apoptosis. ${ }^{10}$ However, little is known about the circumstances of the induction of this apoptotic mechanism. The possibility exists that it can be activated from the onset of granulocytic differentiation. Alternatively, the cells possess endogenous mechanisms capable of inhibiting death signals. The product of the bcl-2 gene is known to protect different cell types from apoptosis. ${ }^{60}$ Inhibition of some isoforms of $\mathrm{PKC}$ by $\mathrm{H} 7$ or calphostin $\mathrm{C}$ reduces bcl-2 gene expression and protein amount in a human erythroleukemia cell line. ${ }^{61}$ It has also been shown that PKC phosphorylates $\mathrm{Bcl}-2$ and this modification of $\mathrm{Bcl}-2$ is associated with the suppression of apoptosis in murine myeloid FDC-PI/ER cell line, Jurkat cells, and human $T$ lymphoblastoid cell line. ${ }^{62,63}$ Recently, it has been demonstrated that suppression of apoptosis in IC.DP murine pre-mast cells correlates with the $\mathrm{PKC} \beta \|$ isoform translocation to the nucleus and up-regulation of $\mathrm{Bcl}-\mathrm{X}_{\mathrm{L}}{ }^{64}$ The expression of bcl-2 is down-regulated during granulocytic differentiation mediated by DMSO and RA. ${ }^{65,66}$ Thus, the co-operation of natural down-regulation and $\mathrm{PKC}$ deficient-dependent hypophosphorylation of Bcl-2 in HL-60 cells induced to differentiate by RA may overcome the threshold of the apoptotic mechanism, which should be activated only in mature cells without suppression of PKC.

In the present study the cell death process in HL-60 cells treated with various combinations of calphostin $\mathrm{C}$ and inducers was investigated by flow cytometry. Cells treated with calphostin $C$ displayed an increased arrest in the G2/M phase of the cell cycle at $24 \mathrm{~h}$ and prolonged exposure of calphostin $C$ led to a significant increase of an apoptotic peak in the subG1 region. The initiation mechanisms of both differentiation and apoptosis deal with the blocking of the cell cycle. The data obtained in this work shows that there is correlation between cell arrest in the G1 phase and differentiation, and the G2/M phase and apoptosis. The blocking of permanently proliferating stem cells in the G1 phase is a prerequisite for cell differentiation and this undoubtedly is a natural event fastened by evolution. Most probably in some cells the initiation of apoptosis might be generated due to an impair mechanism of S-phase of the cell cycle caused by inducers of differentiation. These changes cannot be repaired, however, it allows the cells to enter apoptosis from the G2/M phase. Recently, this phenomenon has been described by. ${ }^{67-71}$

The fact that the pretreatment of HL-60 cells with dbcAMP strongly potentiates RA-induced differentiation and partially protects cells from apoptosis could be explained as follows. In RA-mediated differentiation the native state of PKA activity is necessary for induction and commitment for granulocytic cell differentiation. ${ }^{36}$ Most probably, due to the ability of PKA to block the cell cycle in a variety of cancer cells ${ }^{72}$ it may have synergistically potentiated suppression of the RAinduced progression of cells through the S-phase. Exposing of $\mathrm{HL}-60$ cells to $500 \mu \mathrm{M}$ dbcAMP results in 300 -fold rapid $(3 \mathrm{~h})$ and sustained rise in intracellular cAMP during the commitment stage $(48 \mathrm{~h})$ of differentiation. This results in twofold increase in the number of cells arrested in the G0/G1 phase in comparison to the RA-treated cell population. ${ }^{8}$ In HL-60 cells no or negligible elevations in intracellular cAMP level appeared in response to RA. ${ }^{20,73}$ The positive role of PKA has been established in both the induction and the commitment of HL-60 cell differentiation mediated by vitamin $\mathrm{D}_{3}{ }^{26}$ It is also known that a cAMP responsive element is involved in RA-dependent RAR $\beta 2$ promoter activation. ${ }^{74}$ Therefore, over-expression of $\operatorname{RAR} \beta 2$ in comparison to RXR can change the equilibrium between differentiation and apoptosis to favour the former. ${ }^{75}$ Recently, it has been shown that the elevated level of cAMP markedly inhibits neutrophil apoptosis. ${ }^{76}$ In RA-mediated differentiation besides the basal level of cAMP the activity of adenylate cyclase rises only after $96 \mathrm{~h}^{20}$ Therefore, very high levels (300-fold) of cAMP in dbcAMP pretreated HL-60 cells can synergistically act with cAMP levels after induction by RA. These latter events potentially may protect mature neutrophils against apoptosis in differentiating population. Finally, it should be pointed out that the agents elevating intracellular cAMP levels in HL-60 cells active nuclear factor kappa B $(\mathrm{NF}-\kappa \mathrm{B}) .{ }^{77}$ This transcription regulating factor similarly as $\mathrm{Bcl}-2$ mediates stress-induced cellular survival response (for review see ${ }^{78,79}$ ). However, $\mathrm{Bcl}-2$ and $\mathrm{NF}-\kappa \mathrm{B}$ do not cooperate in suppression of signalling pathways of apoptosis. $^{80}$

In summary, our results reveal the importance of stagespecific PKA and PKC activity in promotion or suppression of apoptosis and differentiation in the promyelocytic leukemia HL-60 cells. Further studies are warranted to more clearly delineate various aspects of this working hypothesis.

\section{Materials and Methods}

\section{Reagents}

RA, dbcAMP, PMA, NBT, RNAse A, proteinase $\mathrm{K}$, ethidium bromide, diphenylamine were purchased from Sigma Chemical Co. (St. Louis, MO, USA). Calphostin C and GF 109203X were from Calbiochem. Agarose DNA grade was from $A B$ Kemila-Preparat. The stock solutions used were: PMA $(1 \mathrm{mg} / \mathrm{ml}), \mathrm{H} 89(2 \mathrm{mM})$, calphostin $\mathrm{C}$ $(1 \mathrm{mM})$ and GF 109203X (1 mM) in DMSO; RA $(500 \mu \mathrm{M})$ in ethanol and dbcAMP $(10 \mathrm{mM})$ in double distilled water. Stock solutions were stored at $-20^{\circ} \mathrm{C}$. In all experiments the stock solutions were diluted in culture medium to obtain the required concentration of the substance of interest.

\section{Cell culture conditions}

The human promyelocytic HL-60 cell line was cultured in RPMI 1640 medium supplemented with $10 \%$ foetal bovine serum, $100 \mathrm{U} / \mathrm{ml}$ penicillin and $100 \mu \mathrm{g} / \mathrm{ml}$ streptomycin (Gibco BRL, Grand Island Laboratories, $\mathrm{NY}, \mathrm{USA}$ ) in a $5 \% \mathrm{CO}_{2}$ humidified incubator at $37^{\circ} \mathrm{C}$. For each experiment, logarithmically grown HL-60 cells were inoculated in $5 \mathrm{ml}$ in $75 \mathrm{ml}$ tissue culture flasks at a density of $4 \times 10^{5} \mathrm{cells} / \mathrm{ml}$. In differentiation experiments, inducers $(350 \mu \mathrm{M}$ dbcAMP and $500 \mathrm{nM}$ $\mathrm{RA})$ and protein kianse inhibitors were added to the culture and the 
cells were incubated for $96 \mathrm{~h}$. In experiments with pretreated cells, the cells were incubated with an inhibitor of protein kinase for $24 \mathrm{~h}$ before induction. It was washed out from the culture medium by centrifugation at $500 \times g$ for $5 \mathrm{~min}$. The pellet was rinsed once with fresh medium in the same manner and resuspended in the medium containing the inducer or both the inducer and the inhibitor of the protein kinase.

\section{Cell viability and growth}

Cell viability was assayed by exclusion of $0.2 \%$ trypan blue. Cell numbers were measured by counting cells in suspension with a haemocytometer. For dose response determination, protein kinase inhibitors were added to a final volume of $5 \mathrm{ml}$ of cell culture treated with inducer, while control cultures were incubated in the absence of inhibitors (for NBT-positive cell determination). The data for cell viability and growth at $96 \mathrm{~h}$ after induction of differentiation were expressed in relation to untreated controls.

\section{NBT reduction assay}

The degree of differentiation was assayed by the ability of cells to reduce NBT to insoluble blue-black formazan on stimulation by PMA. ${ }^{5}$ $100 \mu \mathrm{l}$ of suspension from the culture medium was mixed with an equal volume of $0.2 \%$ NBT dissolved in phosphate-buffered saline containing $40 \mathrm{ng} / \mathrm{ml}$ of PMA and incubated at $37^{\circ} \mathrm{C}$ for $30 \mathrm{~min}$. NBT-positive cells were counted using the haemocytometer. At least 200 cells were scored for each determination, and the number of cells positive for NBT reductivity were expressed as a percentage of the viable cell number.

\section{Detection of apoptosis}

Cell morphology was evaluated using fluorescence microscopy. At the end of each incubation, cells were pelleted at $500 \times g$ for $5 \mathrm{~min}$ and resuspended in $100 \mu \mathrm{l}$ PBS without $\mathrm{Ca}^{2+}$ and $\mathrm{Mg}^{2+}\left(5 \times 10^{6} \mathrm{cells} / \mathrm{ml}\right)$. The extent of apoptosis was determined as the number of cells undergoing nuclear fragmentation and condensation with the presence of cell surface blebs as apoptotic bodies using fluorescence microscopy with $0.01 \%$ acridine orange $/ 0.01 \%$ ethidium bromide mixture $(1: 1, v / v), 6 \mu$ for $100 \mu$ l cell suspension. ${ }^{43}$ At least 300 cells were scored for each determination and the number of cells positive in the test were expressed as the percentage of the total cell number.

\section{Quantitation of DNA fragmentation}

HL-60 cells treated with PK inhibitors for $72 \mathrm{~h}$ were pelleted by centrifugation at $500 \times g$ for $5 \mathrm{~min}$ and rinsed once with PBS. The aliquots of cell suspension $\left(5 \times 10^{6}\right.$ cells) were lysed by addition of $100 \mu \mathrm{l}$ ice-cold lysis buffer containing $5 \mathrm{mM}$ Tris, $20 \mathrm{mM}$ EDTA and $0.5 \%(\mathrm{v} / \mathrm{v})$ Triton X-100, $\mathrm{pH} 8.0$, and samples were allowed to lyse for $15 \mathrm{~min}$ on ice before centrifugation for $15 \mathrm{~min}$ at $13000 \times \mathrm{g}$ in a microcentrifuge to separate intact chromatin (pellet) from DNA fragments (supernatant). ${ }^{44}$ Pellets were resuspended in $300 \mu \mathrm{l}$ of buffer containing $10 \mathrm{mM}$ Tris and $1 \mathrm{mM}$ EDTA, pH 8.0, pellet and supernatant samples were analyzed for DNA content using the diphenylamine reagent. ${ }^{45}$

\section{Isolation of apoptotic DNA fragments}

After harvesting, the cell samples were washed with phosphate buffered saline (PBS) and pelleted by centrifugation. The cell pellets were then treated for $10 \mathrm{~s}$ with lysis buffer ( $1 \%$ Nonidet P-40 in $20 \mathrm{mM}$ EDTA, $50 \mathrm{mM}$ Tris- $\mathrm{HCl}$, pH 7.5; $10 \mu \mathrm{l}$ per $10^{6}$ cells, minimum $50 \mu \mathrm{l}$ ).
After centrifugation for $5 \mathrm{~min}$ at $1600 \times g$ the supernatant was collected and the extraction was repeated with the same amount of lysis buffer. The supernatants were brought to $1 \%$ SDS and treated for $2 \mathrm{~h}$ with RNAse A (final concentration $2.5 \mu \mathrm{g} / \mu \mathrm{l}$ ) at $56^{\circ} \mathrm{C}$ followed by digestion with proteinase $\mathrm{K}$ (final concentration $2.5 \mu \mathrm{g} / \mu \mathrm{l}$ ) for at least $2 \mathrm{~h}$ at $37^{\circ} \mathrm{C}$. After addition of $1 / 2 \vee 10 \mathrm{M}$ ammonium acetate, DNA was precipitated with $2.5 \mathrm{vol}$. ethanol and dissolved in TE buffer (10 mM Tris- $\mathrm{HCl}, 1 \mathrm{mM}$ EDTA, $\mathrm{pH}$ 8.0). ${ }^{46}$

\section{Electrophoresis of DNA}

DNA $(15 \mu \mathrm{g})$ in $10 \mu \mathrm{l}$ of TAE buffer containing 0.2 vol. $30 \%$ glycerol, $0.25 \%$ bromphenol blue was loaded into each well and electrophoresed on a $1.5 \%$ agarose gel containing TAE running buffer $(40 \mathrm{mM}$ Tris-acetate, $20 \mathrm{mM}$ sodium acetate, $2 \mathrm{mM}$ EDTA, pH 7.8) at $100 \mathrm{~V}$ for $2-3 \mathrm{~h}$. The agarose gel was stained with ethidium bromide for $10 \mathrm{~min}$ and destained in $\mathrm{H}_{2} \mathrm{O}$. The DNA was visualised by UV illumination. The DNA marker of 123 base pairs was used as a molecular weight standard (Sigma Chemical Co. USA).

\section{Cell cycle analysis}

Untreated or drug treated cells were collected by centrifugation, suspended in PBS and fixed in ice-cold $70 \%$ ethanol (ratio 1:10) for $24 \mathrm{~h}$ at $-20^{\circ} \mathrm{C}$. Fixed cells were split into two aliquots. The cells from first aliquot were centrifuged at $800 \times g$ for 5 min and cell pellet (from $1-2 \times 10^{6}$ cells $/ \mathrm{ml}$ ) were resuspended in $40 \mu \mathrm{l}$ of phosphate-citrate buffer, consisting of 192 parts of $0.2 \mathrm{M} \mathrm{Na}_{2} \mathrm{HPO}_{4}$ and eight parts of $0.1 \mathrm{M}$ citric acid $\left(\mathrm{pH} \mathrm{7.8)}\right.$ at room temperature for at least $30 \mathrm{~min}^{47}$ After centrifugation at $1000 \times \mathrm{g}$ for $5 \mathrm{~min}$, the cells were suspended in $1 \mathrm{ml}$ PBS containing propidium iodide (PI) $(50 \mathrm{mg} / \mathrm{ml})$ and RNAse $(0.2 \mathrm{mg} / \mathrm{ml})$ in polypropylene tubes and incubated at room temperature for $30 \mathrm{~min}$. The tubes were then placed at $4^{\circ} \mathrm{C}$ in the dark before the flow cytometric analysis using a FACscan flow cytometer (BectonDickinson, USA), LysisIl, Ver 1.1 software. The data were registered on a logarithmic scale. Apoptotic cells were detected on PI histogram as a hypodiploid peak. Fixed cells from second aliquot were stained with $\mathrm{PI}$, as described earlier. Samples were analyzed on a flow cytometer. The percentage of cells in $\mathrm{G} 1, \mathrm{~S}$ and $\mathrm{G} 2 / \mathrm{M}$ was evaluated with CellFITT software.

\section{Acknowledgements}

The study was supported by fellowships from the Swedish Institute to Jurate Savickiene and the University of Umeå to Arunas Gineitis, and Lithuanian State Science and Studies Foundation, No 98802. Authors are grateful to Drs. Dainius Characiejus and Olga Nagaeva for technical assistance in flow cytometric analysis, and Dr. Gediminas Cepinskas for critical reading of this manuscript.

\section{References}

1. Sundström C and Nilsson K (1976) Establishment and characterisation of a human histocytic lymphoma cell line (U-937). Int. J. Cancer 565-577

2. Koffler HP and Golde DW (1978) Acute myelogenic leukemia: a human cell line responsive to colony stimulating activity. Science 200: 1153-1158

3. Tsuchiya S, Yamabe M, Yamaguchi Y, Kobayashi Y, Konno T and Tada K (1980) Establishment and characterisation of a human acute monocytic leukemia cell line (THP-1). Int. J. Cancer 26: 171-176

4. Minowada J (1982) Immunology of leukemic cells. In Leukemia, Gunz F and Henderson E, (eds) (New York, Grune \& Stratton) pp 119-134 
5. Collins S (1987) The HL-60 promyelocytic leukemia cell line: proliferation, differentiation and cellular oncogen expression. Blood 70: 1233-1244

6. Lanotte V, Martin-Thouvenin S, Najman S, Balerini P, Valensi F and Berger R (1991) NB4, a maturation inducible cell line with $\mathrm{t}(15 ; 17)$ marker isolated from a human acute promyelocytic leukemia (M3). Blood 7: 1080-1086

7. Collins SJ, Gallo RC and Gallagher RE (1977) Continuous growth and differentiation of human myeloid leukemic cells in suspension culture. Nature 270: $347-349$

8. Chaplinski TJ and Niedel JE (1982) Cyclic nucleotide-induced maturation of human promyelocytic leukemia cells. J. Clin. Invest. 70: 953-964

9 Breitman TR and He R (1990) Combinations of retinoic acid with either sodium butyrate, dimethyl sulfoxide, or hexamethylene bisacetamide synergistically induce differentiation of the human myeloid leukemia cell line HL-60. Cancer Res. 50: 6268-6273

10. Savill JS, Wyllie AH, Henson JE, Walport MJ, Henson PM and Haslett S (1988) Macrophages phagocytosis of ageing neutrophils in inflammation. J. Clin. Invest. 83: $856-875$

11. Martin SJ, Bradley GJ and Cotter TG (1990) HL-60 cells induced to differentiate towards neutrophils subsequently die via apoptosis. Clin. Exp. Immunol. 79 : 448-453

12. Tosi P, Visani G, Gibellini D, Zauli G, Ottaviani E, Cenacchi A, Gamberi B, Manfroi S, Marchisio M and Tura S (1994) All-trans retinoic acid and induction of apoptosis in acute promyelocytic leukemia cells. Leukem. Lymphoma 14: $503-$ 507

13. Jarvis WD, Turner AJ, Povirk LF, Traylor RS and Grant S (1994) Induction of apoptotic DNA fragmentation and cell death in $\mathrm{HL}-60$ human promyelocytic leukemia cells by pharmacological inhibitors of protein kinase C. Cancer Res. 54 $1707-1714$

14. Nagy L, Thomazy VA, Shipley GL, Fesus L, Lamph W, Heyman RA, Chandraratna RAS and Davies PJA (1995) Activation of retinoid X receptors induces apoptosis in HL-60 cell lines. Mol. Cell. Biol. 15: 3540-3551

15. Huang ME, Ye YC, Chen SR, Chai JR, Lu HX, Zhoa L, Gu LJ and Wang Z (1988) Use of all-trans retinoic acid in the treatment of acute promyelocytic leukemia. Blood 72: 567-574

16. Castaigne $\mathrm{S}$, Chomienne $\mathrm{C}$, Daniel MT, Ballerini $\mathrm{P}$, Berger R, Fenaux $\mathrm{P}$ and Degos $L$ (1990) All-trans retinoic acid as a differentiation therapy for acute promyelocytic leukemia. Clinical results. Blood 76: 1704-1712

17. Dombret H, Castaigne S, Fenaux P, Chomienne C and Degos L (1994) Induction treatment of acute promyelocytic leukemia using all-trans retinoic acid. Controversies about dosage, advantages and side-effect management. Leukemia 8 Suppl 3: S73-S75

18. Elias $L$ and Stewart $T$ (1984) Subcellular distribution of cyclic adenosine $3^{\prime}: 5^{\prime}$ monophosphate-dependent protein kinase during the chemically induced differentiation of HL-60 cells. Cancer Res. 44: $3075-3080$

19. Fontana JA, Emler C, Ku K, McClung JK, ButcherFRand Durham L (1984)Cyclic AMP-dependent and -independent protein kinases and protein phosphorylation in human promyelocytic leukemia ( $\mathrm{HL}-60)$ cells induced to differentiate by retinoic acid. J. Cell. Physiol. 120: 49-60

20. Fontana J, Miksis G and Durham J (1987) Elevation of adenylate cyclase activity during leukemic cell differentiation. Exp. Cell. Res. 168: 487-493

21. Makowske M, Ballester R, Cayre $Y$ and Rosen OM (1988) Immunochemica evidence that three protein kinase $\mathrm{C}$ isozymes increase in abundance during $\mathrm{HL}$ 60 differentiation induced by dimethyl sulfoxide and retinoic acid. J. Biol. Chem. 263: $3402-3410$

22. Hashimoto K, Kishimoto A, Aihara H, Yasuda I, Mikawa K, Kiss Z, Deli E and Kuo JF (1989) Temporal changes in intracellular distribution of protein kinase C during differentiation of human leukemia $\mathrm{HL}-60$ cells induced by phorbol ester. FEBS Lett. 231: 41-46

23. Nishizuka $Y$ (1990) Protein kinase $C$ during differentiation of human promyelocytic leukemia cell line, HL-60. FEBS Lett. 263: 31-34

24. Aihara H, Asaoka Y, Yoshida Y and Nishizuka Y (1991) Sustained activation of protein kinase $\mathrm{C}$ is essential to $\mathrm{HL}-60$ cell differentiation to macrophage. Proc. Natl. Acad. Sci. USA 88: 11062-11066

25. Hocevar BA and Fields AP (1991) Selective translocation of $\beta$ II-protein kinase $C$ to the nucleus of human promyelocytic (HL-60) leukemia cells. J. Biol. Chem. 266: $28-33$

26. Okuda T, Sawada H, Kato Y, Yumoto Y, Ogawa K, Tashima M and Okuma M (1991) Effects of protein kinase A and calcium/phospholipid-dependent kinase modulators in the process of $\mathrm{HL}-60$ cell differentiation: their opposite effects between HL-60 and K-562 cell differentiation. Cell Growth Differ. 2: 415-420
27. Torota G, Yokozaky H, Pepe S, Clair T and Cho-Chung YS (1991) Differentiation of $\mathrm{HL}-60$ leukemia by type regulatory antisense oligodeoxynucleotide of CAMPdependent protein kinase. Proc. Natl. Acad. Sci. USA 88: 2011-2015

28. Hardy SJ, Haylock DN, Lopez AF and Murray AW (1992) Examination of the role of the proteolytically activated form of protein kinase $\mathrm{C}$ in the differentiation of human haemopoietic cells. Differentiation 50: 189-202

29. Hui EK-W and Yung BY-M (1992) Protein kinase $C$ activity during sphinganine potentiation of retinoic acid-induced differentiation in a human leukemia cell line (HL-60). Life Sci. 51: 415-422

30. Tanaka $\mathrm{Y}$, Yoshihara K, Tsuyuki M, Itaya-Hironaka A, Inada $\mathrm{Y}$ and Kamiya $T$ (1992) Retinoic acid-specific induction of a protein kinase $C$ isoform during differentiation of HL-60 cell. J. Biochem. 111: 265-271

31. Kurie JM, Younes A, Miller Jr WH, Burchet M, Chiu CF, Kolesnik R and Dimitrovsky E (1993) Retinoic acid stimulates the protein kinase C pathway before activation of its $\beta$-nuclear receptor during human teratocarcinoma differentiation. Biochim. Biophys. Acta 1179: 203-207

32. Rohlff C, Clair T and Cho-Chung YS (1993) 8-Cl-cAMP induces truncation and downregulation of the RI $\alpha$ subunit and up-regulation of the RII $\beta$ subunit of CAMPdependent protein kinase leading to type II holoenzyme-dependent growth inhibition and differentiation of HL-60 leukemia cells. J. Biol. Chem. 268: 57745782

33. MacFarlane DE and Manzel L (1994) Activation of $\beta$-isozyme of protein kinase C $(\mathrm{PKC} \beta)$ is necessary and sufficient for phorbol ester-induced differentiation of HL-60 promyelocytes. J. Biol. Chem. 269: 4327-4331

34. Yung BY-M, Hsiao T-F, Wei LL-L and Hui EK-W (1994) Sphinganine potentiation of dimethyl sulfoxide-induced granulocytic differentiation, increase of alkaline phosphatase activity and decrease of protein kinase $C$ activity in a human leukemia cell line (HL-60). Biochem. Biophys. Res. Commun. 199: 888-896

35. Zauli G, Visani G, Bassini A, Caramelli E, Ottaviani E, Bertolaso L, Bertagnolo V, Borgatti P and Capitani S (1996) Nuclear translocation of protein kinase C- $\alpha$ and $-\zeta$ isoforms in $\mathrm{HL}-60$ cells induced to differentiate along the granulocytic lineage by all-trans retinoic acid. Brit. J. Haematol. 93: 542-550

36. Savickiene J, Gineitis A, Shanbhag VP and Stigbrand T (1995) Protein kinase inhibitors exert stage specific and inducer dependent effects on HL-60 cell differentiation. Anticancer Res. 15: 687-692

37. Savickiene J, Gineitis A, Shanbhag VP and Stigbrand T (1997) Relationship between differentiation mechanisms involving cAMP-dependent protein kinase and protein kinase $\mathrm{C}$ in uninduced and differentiating HL-60 cells. Anticancer Res. 17: 285-292

38. Nonaka T, Mio M, Doi M and Tasaka K (1992) Histamine-induced differentiation of $\mathrm{HL}-60$ cells. The role of CAMP and protein kinase A. Biochem. Pharmacol. 44: $1115-1121$

39. Gorczyca W, Gong J, Ardelt B, Traganos F and Darzynkiewicz Z (1993) The cell cycle related differences in susceptibility of $\mathrm{HL}-60$ cells to apoptosis induced by various tumor agents. Cancer Res. 53: 3186-3192

40. Traganos E, Knulti-Hotz M, Gorczyca W, Ardlet B and Darzynkiewicz Z (1993) The protein kinase $\mathrm{C}$ inhibitor $\mathrm{H} 7$ blocks normal human lymphocyte stimulation and induced apoptosis of both normal lymphocytes and MOLT-4 leukemia cells. Int. J. Oncol. 2: 47-59

41. Lannote M, Riviere JB, Hermouet S, Houge G, Vintermyr OK, Gjersten BT and Doskeland SO (1991) Programmed cell death (apoptosis) is induced rapidly and with positive cooperativity by activation of cyclic adenosine monophosphatekinase I in a myeloid leukemia cell line. J. Cell. Physiol. 146: 73-80

42. de Vente J, Kiley S, Garris T, Bryant W, Hooker J, Posekany K, Parker P, CookP, FletcherD and Ways DK (1995) Phorbol ester treatment of U937 cells with altered protein kinase $C$ content and distribution induces cell death rather than differentiation. Cell Growth Differ. 6: 371-382

43. Mercille S and Massie B (1994) Induction of apoptosis in nutrient-deprived cultures of hybridoma and myeloma cells. Biotechnol. Bioengineer 44: $1140-$ 1154

44. McConkey DJ, Hartzel P, Nicotera P and Orrenius S (1989) Calcium activated DNA fragmentation kills immature thymocytes. FASEB J. 3: 1843-1849

45. Burton K (1956) A study of the conditions and mechanism of the diphenylamine reaction for the colorimetric estimation of deoxyribonucleic acid. Biochem. J. 62: $315-323$

46. Herman M, Lorenz HM, Voll R, Grunke M, Woit W and Kalden JR (1994) A rapid and simple method for the isolation of apoptotic DNA fragments. Nucl. Acid Res. 22: 5506-5507 
47. Gong J, Traganos F and Darzynkiewicz Z (1994) A selective procedure for DNA extraction from apoptotic cells applicable for gel electrophoresis and flow cytometry. Anal. Biochem. 218: 314-319

48. Martin P and Papayannopoulou T (1982) HEL cells: a new human erythroleukemia cell line with spontaneous and induced globin expression. Science 216: 1233-1235

49. Chorvati B and Sedlak J (1996) Protein kinase inhibitors: induction of apoptosis and drug-resistance modulation in neoplastic cell lines. Neoplasma 43:3-9

50. Anzai N, Kawabata H, Hirama T, Masutani H, Ohmori M, Yoshida Y and Okuma M (1994) Marked apoptosis of human myelomonocytic leukemia cell line P39: significance of cellular differentiation. Leukemia 8: 446-453

51. DelBino G, LiX, Traganos F and Darzynkiewicz Z (1994) Altered susceptibility of differentiating HL-60 cells to apoptosis induced by antitumor drugs. Leukemia 8: $281-288$

52. Park JR, Robertson K, Hickstein DD, Tsai S, Hockenbery DM and Collins SJ (1994) Dysregulated bcl-2 expression inhibits apoptosis but not differentiation of retinoic acid-induced HL-60 granulocytes. Blood 84: 440-445

53. Xu H, Tepper CG, Jones JB, Fernandes CE and Studzinski GP (1993) 1,25 dihydroxyvitamin $\mathrm{D} 3$ protects $\mathrm{HL}-60$ cells against apoptosis but down regulates the expression of the Bcl-2 gene. Exp. Cell. Res. 209: 367-375

54. Solary E, Bertrand R, Kohn KW and Pommier Y (1993) Differential induction of apoptosis in undifferentiated and differentiated HL-60 cells by DNA topoisomerase I and II inhibitors. Blood 81: 1359-1366

55. Ketley NJ, Allen PD, Kelsey SM and Newland AC (1997) Modulation of idarubicin-induced apoptosis in human acute myeloid leukemia blasts by alltrans retinoic acid, $1,25(\mathrm{OH})_{2}$ vitamin $\mathrm{D}_{3}$, and granulocyte-macrophage colonystimulating factor. Blood 90: 4578-4587

56. Lotem J and Sachs L (1989) Induction of dependence on hematopoietic proteins for viability and receptor upregulation in differentiating myeloid leukemic cells. Blood 74: 579-585

57. Lotem J, Cragoe JrEJ and Sachs L (1991) Rescue from programmed cell death in death in leukemic and normal myeloid cells. Blood 78: 953-960

58. Evan GI, Brown L, Whyte M and Harrington E (1995) Apoptosis and the cell cycle. Curr. Opin. Cell. Biol. 7: 825-834

59. Ferraris C, Cooklis N, Polakowska RR and Haake AR (1997) Induction of apoptosis through the PKC pathway in cultured dermal papilla fibroblasts. Exp. Cell. Res. 234: 37-46

60. Korsmeyer SJ (1992) Bcl-2 inhibits a new category of oncogenes: regulators of cell death. Blood 80: 879-886

61. Rinaudo MS, Su K, Halder LA and Mufson AD (1995) Human interleukin-3 receptor modulated bcl-2 mRNA and protein levels through protein kinase $\mathrm{C}$ in TF-1 cells. Blood 86: $80-86$

62. May MS and Ghosh S (1998) Signal transduction through NF- $\kappa$ B. Immunol. Today 19: $80-88$

63. Chen YCandFallerDV (1995) Direction of $p 21^{\text {ras }}$-generated signals towards cell growth or apoptosis is determinated by protein kinase $\mathrm{C}$ and $\mathrm{Bcl}-2$. Oncogene 11: 1487- 1498

64. Chen Q, Turner J, Watson JM and Dive C (1997) v-Abl protein tyrosine kinase (PTK) mediated suppression of apoptosis is associated with the up-regulation of Bcl-X . Oncogene 15: 2249-2254
65. Delia D, Aiello A, Soligo D, Fontanella E, Pezzella F, Pierotti MA and Della Porta G (1992) bcl2 proto-oncogene expression in normal and neoplastic human myeloid cells. Blood 79: 1291-1298

66. Naumovski L and Cleary M (1994) Bcl2 inhibits apoptosis associated with terminal differentiation of HL-60 myeloid leukemia cells. Blood 83: 2261-2267

67. Begemann M, Kashimawo SA, Choi YJA, Kim S, Christiansen KM, Duigou G, Mueller M, Schieren I, Ghloch S, Fabbro D, Lampen NM, Heitjan DF, Schiff PB, Bruce JN and Weinstein IB (1996) Inhibition of the growth of glioblastomas by CGP 41251, an inhibitor of protein kinase C, and by a Phorbol ester tumor promoter. Clin. Cancer Res. 2: 1017-1030

68. Begemann M, Kachimawo SA, Lunn RM, Delohery T, ChoiYJ, Kim S, Heitjan DF Santella RM, Schiff PB, Bruce JN and Weinstein IB (1998) Growth inhibition induced by $\mathrm{R} 032-8220$ and calphostin $\mathrm{C}$ in human glioblastoma cell lines is associated with apoptosis and inhibition of CDC2 kinase. Anticancer Res. 18 3139-3152

69. Bunz F, Dutriaux A, Lengauer C, Waldman T, Zhou S, Brown JP, Sedivy JM, Kinzler KW and Vogelstein B (1998) Requirement for p53 and p21 to sustain G2 arrest after DNA damage. Science 282: 1497-1501

70. Li F, Ambrosini G, Chu EY, Plescia J, Tognin S, Marchisio PC and Altieri DC (1998) Control of apoptosis and mitotic spindle checkpoint by survivin. Nature 10 $580-584$

71. Sleiman RJ, Catchpoole DR and Stewart BW (1998) Drug-induced death of leukemic cells after G2/M arrest: higher order DNA fragmentation as an indicato of mechanism. Br. J. Cancer 77: 40-50

72. Boynton AL and Whitfield JF (1983) The role of cyclic AMP in cell proliferation. A critical assessment of the evidence. Adv. Cyclic Nucleotide Res. 15: 193-294

73. Meisner JD, Brown GA, Mueller WH and Scheibe RJ (1996) Retinoic acidmediated decrease of Gas protein expression: involvement of Gas in the differentiation of HL-60 myeloid cells. Exp. Cell. Res. 225: 112-121

74. Kruyt FAE, Folkers G, van den Brink CE and van der Saag PT (1992) A cyclic AMP response element is involved in retinoic acid-dependent $R A R \beta 2$ promote activation. Nucl. Acid Res. 20:6393-6399

75. Brooks III SC, Sturgill R, Choi J and Yen A (1997) An RXR-selective analogue attenuates the RAR $\alpha$-selective analogue-induced differentiation and non- $\mathrm{G}_{1}$ restricted growth arrest of NB4 cells. Exp. Cell. Res. 234: 259-269

76. Rossi AG, Cousin JM, Dransfield I, Lawson MF, Chilvers ER and HaslettC (1995) Agents that elevate cAMP inhibit human neutrophil apoptosis. Biochem. Biophys. Res. Commun. 217: 892-899

77. Serkkola E and Hurme M (1993) Activation of NF- $\kappa$ B by cAMP in human myeloid cells. FEBS Lett. 334: $327-330$

78. Baeurele PA and Baltimore D (1996) NF- $\kappa$ B: ten years after. Cell 87: 13-20

79. May WS, Tyler PG, Ito T, Armstrong DK, Qatsha KA and Davidson NE (1994) Interleukin-3 bryostatin-1 mediated hyperphosphorylation of Bcl2 $\alpha$ in association with suppression of apoptosis. J. Biol. Chem. 269: 26865-26870

80. McDonnell TJ (1997) Bcl-2 suppresses apoptosis resulting from disruption of the $\mathrm{NF}-\kappa \mathrm{B}$ survival pathway. Exp. Cell. Res. 237: 101-109 